\author{
HALINA WIŚNIEWSKA ${ }^{1}$ \\ MACIEJ MAJKA ${ }^{1}$ \\ MAGDALENA GAWLOWSKA ${ }^{1}$ \\ MAREK KORBAS ${ }^{2}$ \\ JOLANTA BELTER ${ }^{1}$ \\ ${ }^{1}$ Instytut Genetyki Roślin, Polska Akademia Nauk, Poznań \\ ${ }^{2}$ Instytut Ochrony Roślin, Państwowy Instytut Badawczy, Poznań \\ Kierownik Tematu: prof. dr hab. Halina Wiśniewska Instytut Genetyki Roślin, Polska Akademia Nauk, \\ Strzeszyńska 34, 60-479 Poznań, tel.662044293, e-mail: hwis@igr.poznan.pl
}

Prace zostały wykonane $w$ ramach badan podstawowych na rzecz postępu biologicznego $w$ produkcji roślinnej na podstawie decyzji Ministra Rolnictwa $i$ Rozwoju Wsi nr HOR.hn. 802.18.2018, Zadanie 2.

\title{
Wykorzystanie markerów molekularnych i fenotypowych do identyfikacji genów odporności pszenicy na łamliwość źdźbła powodowaną przez Oculimacula yallundae i Oculimacula acuformis
}

The use of molecular and phenotypic markers to identify genes of wheat resistance to eyespot caused by Oculimacula yallunda and Oculimacula acuformis

Słowa kluczowe: geny $P c h 1, P c h 2$, łamliwość źdźbła, markery molekularne, Oculimacula, pszenica

\section{WSTEP}

Łamliwość źdźbła to jedna z najważniejszych chorób pszenicy uprawnej (Triticum aestivum L.) Powodowana jest przez dwa grzyby patogeniczne Oculimacula yallundae i O. acuformis. Szczególnie podczas łagodnych zim i chłodnych wiosen, na zewnętrznych pochwach liści pszenicy występują bursztynowo-brązowe plamy. W trakcie wegetacji patogen z pochew liściowych przedostaje się na podstawy źdźbła, gdzie na obszarze plam w źdźble tworzy się watowata grzybnia. Skutkiem tego podstawa źdźbła próchnieje i powoduje łamliwość źdźbła, co może powodować ubytek plonu nawet do 50\%. Istnieje kilka źródeł odporności na łamliwość podstawy źdźbła, lecz dotąd tylko dwa geny, Pch1 i Pch2 zostały przeniesione do pszenicy uprawnej i warunkują odporność. Gen Pch1 jest najbardziej efektywny, został zidentyfikowany w Aegilops ventricosa i translokowany do długiego ramienia chromosomu 7D heksaploidalnej pszenicy (Maia i in., 1967). 
Nie zapewnia on całkowitej odporności rośliny, jednakże znacząco redukuję skalę porażenia. Drugim genem, który w mniejszym stopniu warunkuje odporność na łamliwość źdźbła jest Pch2 zlokalizowany na dłuższym ramieniu chromosomu 7A pszenicy odmiany „Capelle-Desprez” (Burt i in., 2014).

Cele badań w roku 2018:

— piramidyzacja genów odporności Pch1 i Pch2 na łamliwość źdźbła u pszenicy.

- Identyfikowanie w gentypach pszenicy ozimej obecności genu Pchl przy użyciu markera izoenzymatycznego w postaci endopeptydazy EpDlb oraz genów Pchl i Pch2 przy użyciu markerów SSR,

— ocena porażenia siewek genotypów pszenicy (test w fitotronie) i dojrzałych źdźbeł (test polowy) po inokulacji zawiesiną grzybni i zarodników O. yallundae i $O$. acuformis oraz ocena naturalnego porażenia w lokalizacjach,

— analiza elementów struktury plonu badanych form - określenie wpływu genów Pch1 i Pch2 na cechy agronomiczne.

\section{MATERIAŁY I METODY}

Materiał badawczy dla piramidyzacji genów Pch1 i Pch2 stanowiły formy pszenicy z genami Pch1 i Pch2 wyselekcjonowane we wcześniejszych badaniach oraz formy bez tych genów - temat badawczy nr 1. Materiał do identyfikacji w genotypach pszenicy genów Pch1 i Pch2 oraz do oceny podatności genotypów pszenicy na łamliwość źdźbła w testach inokulacyjnych siewkowych i polowych stanowiło 200 genotypów pszenicy ozimej o zróżnicowanym podłożu genetycznym, trzy odmiany kontrolne, odm. Rendezvous — wzorzec odporności — temat badawczy nr 2 i 3.

\section{WYNIKI}

\section{Temat badawczy 1}

Krzyżowania genotypów wybranych na podstawie wcześniejszych badań w celu piramidyzacji genów Pch1 i Pch2

Wykonano krzyżowania wewnątrzgatunkowe (3 kombinacje) form pszenicy o stwierdzonej wcześniej podwyższonej odporności na patogeny z rodzaju Oculimacula oraz ze zidentyfikowanymi przy pomocy markerów molekularnych genów Pch1 i Pch2 związanych z odpornością na te patogeny oraz formy bez genów Pch1 i Pch2. Uzyskano 236 ziarniaków mieszańcowych.

\section{Temat badawezy 2}

Wytworzenie skutecznego systemu markerów do identyfikacji molekularnej spiramidyzowanych genów $P$ chl 1 i $P$ ch 2

W badaniach wykorzystano 5 markerów molekularnych (tab. 1). Wykazano obecność markerów Pch1 i/lub Pch2 w 25 genotypach pszenicy ozimej. U odmiany odpornej Rendezvous, a także w 5 badanych genotypach pszenicy stwierdzono przy pomocy markera izoenzymatycznego EpDlb i markerów molekularnych Xust2001, Xorw1 obecność genu Pch1, a za pomocą pozostałych markerów molekularnych Xcfa2040, 
Xwmc525 obecność genu Pch2. Geny te warunkują odporność pszenicy na grzyby patogeniczne z rodzaju Oculimacula, wywołujące chorobę zwaną łamliwością źdźbła (15,4\% badanego materiału); u 5 z tych genotypów potwierdzono obecność genu Pch 1 i $P$ ch 2 również pozostałymi użytymi w badaniach markerami.U kolejnych 4 genotypów pszenicy zaobserwowano przerwanie sprzężenia markera Xust2001 z genem Pch1, wykazano obecność genów $P$ chl i $P$ ch2 pozostałymi markerami.

U 49 linii pszenicy ozimej stwierdzono tylko gen Pch2, a u pozostałych badanych genotypów pszenicy nie stwierdzono obecności genów Pch1 Pch2.

Tabela 1

Markery molekularne wykorzystane w badaniach

\begin{tabular}{|c|c|c|c|}
\hline Lp. & Marker & Gen & Lokalizacja w chromosomie \\
\hline 1 & EpDIb (izoenzymatyczny) & Pch1 & $7 \mathrm{D}$ \\
\hline 2 & Xust 2001 & Pch1 & 7D \\
\hline 3 & Xorw1 & Pchl & $7 \mathrm{D}$ \\
\hline 4 & Xcfa2040 & Pch2 & $7 \mathrm{~A}$ \\
\hline 5 & Xwmc525 & Pch2 & 7A \\
\hline
\end{tabular}

\section{Temat badawczy 3}

Testy inokulacyjne badanych genotypów pszenicy oraz obserwacje naturalnego porażenia genotypów przez $O$. acuformis i $O$. yallundae na poletekach doświadczalnych w kilku miejscach Polski.

Zbiór materiału roślinnego inokulowanego oraz analiza porażenia przez $O$. acuformis i $O$. yallundae w celu selekcji genotypów odpornych. Analiza korelacji między cechami fenotypowymi roślin a ich odpornością na łamliwość podstawy źdźbła.

Nie obserwowano naturalnego porażenia pszenicy $w$ naturalnych warunkach. Genotypy z genami Pch1 i Pch2 cechowały się najmniejszym porażeniem siewek Genotypy posiadające tylko gen $P c h l$ wykazywały niższe porażenie siewek, niż genotypy posiadające tylko gen $P c h 2$. Taka sama zależność obserwowana była dla inokulacyjnego testu polowego. Wykazano, że obecność genów Pch1 i Pch2 lub ich brak nie wpływała istotnie na plon ziarna z poletka. Stwierdzono brak istotnego wpływu obecności genów Pch1, Pch2 lub ich braku na masę tysiąca ziarniaków (MTZ).

Wykazano, że obecność genów Pch1 i Pch2 lub ich brak nie wpływała istotnie na plon ziarna z poletka, chociaż plon był najwyższy przy obecności obu genów. Obserwowano również brak istotnego wpływu obecności genów Pch1, Pch2 lub ich braku na masę tysiąca ziarniaków.

\section{WNIOSKI}

1. Z kombinacji krzyżówkowych związanych z piramidyzację u pszenicy genów Pchl i Pch2 uzyskano 236 ziarniaków mieszańcowych — temat badawczy 1.

2. U odmiany odpornej Rendezvous, a także w 5 genotypach pszenicy stwierdzono przy pomocy markera izoenzymatycznego EpDlb i markerów molekularnych Xust2001, Xorwl obecność genu Pchl, a za pomocą pozostałych markerów molekularnych 
Xcfa2040, Xwmc525 obecność genu Pch2 (15,4\% badanego materiału) - temat badawczy nr 2.

3. U 49 genotypów pszenicy stwierdzono tylko gen Pch2 - temat badawczy nr 2.

4. Genotypy z genami $P \operatorname{ch} 1$ i $P$ ch 2 cechowały się najmniejszym porażeniem siewek temat badawczy nr 3.

5. Genotypy posiadające tylko gen $P c h l$ wykazywały niższe porażenie siewek, niż genotypy posiadające tylko gen Pch2. Taka sama zależność obserwowana była dla inokulacyjnego testu polowego - temat badawczy nr 3.

6. Wykazano, że obecność genów Pch1 i Pch2 lub ich brak nie wpływała istotnie na plon ziarna z poletka i masę tysiąca ziarniaków - temat badawczy 3.

\section{LITERATURA:}

Burt C., Hollins T. W., Nicholas P. 2014. Identification of a QTL conferring seedling and adult plant resistance to eyespot on chromosome 5A of Cappelle Desprez. Theor. Appl. Genet. 122: 119 - 128.

Maia N. 1967. Obtention de blés tendres résistants au piétin-verse (Cercosporella herpotrichoides) par croisements interspécifiqu. es. CR Acad. Agric. Fr. 52: 149 - 154. 